\title{
Die betroubaarheid van die apostels en hulle getuienis volgens 2 Petrus 1:3-4 en die betekenis daarvan vir die geskrifte van die Nuwe Testament: 'n Eksegetiese studie
}

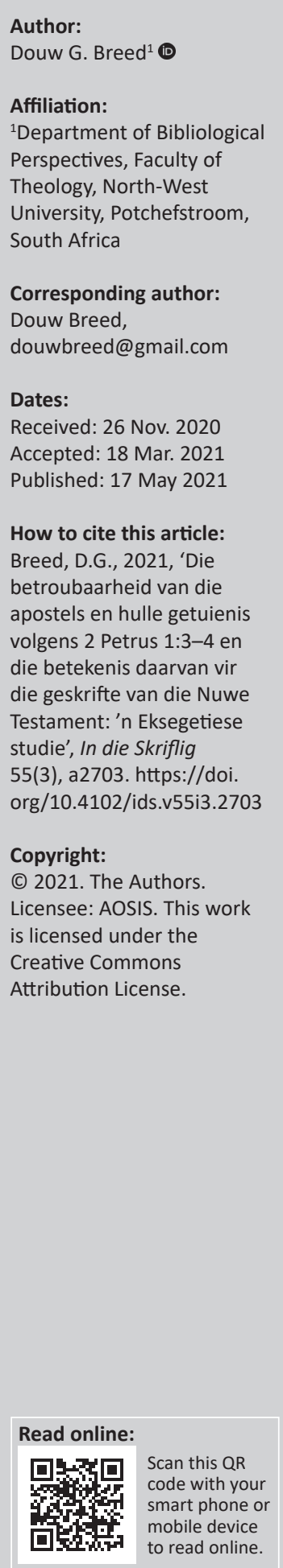

The reliability of the apostles and their testimony according to 2 Peter 1:3-4 and its significance for the writings of the New Testament: An exegetical study. In this exegetical article, it is shown that, in 2 Peter 1:3-4, Peter indicates that the apostles were reliable witnesses of Jesus Christ. As the New Testament writings are bearers of the apostolic testimony, 2 Peter 1:3-4 also provides important testimony regarding the Bible and, in particular, regarding the New Testament. The aim of this article is to show that, according to 2 Peter 1:3-4, the apostles and their testimony are reliable and that these testimonies are significant for the writings of the New Testament. This study follows an exegetical method and follows the grammatical-historical model. From 2 Peter 1:3-4, it is clear that the reliability of the apostles is the result of divine power. Jesus Christ worked through his Spirit with divine power in the apostles. Through the Holy Spirit, Jesus Christ provides the apostles with everything that leads to true life, as well as to godliness. To the apostles, this was all given within their intimate and personal relationship with the glorified Christ. According to 2 Peter 1:3-4, Jesus Christ himself called his apostles to proclaim the message of God's grace. As eye- and earwitnesses of Jesus Christ's divine power, they could reliably reveal the meaning of what they witnessed of him. In 2 Peter 1:3-4, Peter testifies that the apostles received promises from Jesus Christ. These are great promises that have profound significance for anyone who accepts them in faith.

Contribution: The contribution of this article is to show that 2 Peter 1:3-4 gives important information about the reliability of the apostles and their testimony.

Keywords: 2 Peter 1:3-4; apostels; goddelike krag; betroubaarheid; 'E $\pi$ í $\gamma \omega \sigma 1$; beloftes; Nuwe Testament; roep.

\section{Inleiding}

Reeds vroeg in die kerk se geskiedenis is die besondere plek wat aan Jesus Christus se apostels gegee is, erken. Ignasius vergelyk in sy brief aan die Romeine (Rom 4:3) homself met die apostels en sê: 'I do not give you orders like Peter and Paul: they were apostles; I am a convict ...' (Holmes, Lightfoot \& Harmer 2007:229). Clemens (1 Clem 45:1-2) sê: 'The apostles received the gospel for us from the Lord Jesus Christ; Jesus the Christ was sent forth from God. So then, Christ is from God, and the apostles are from Christ. Both, therefore, came of the will of God in good order' (Holmes et al. 2007:101). Coetzee (1984:75-77) beklemtoon die besondere plek van die apostels. Hy sê dat toe Jesus Christus na sy Vader teruggekeer het, Hy iets van sy gesag aan sy kerk deurgegee het. Hy gee dit egter alleen in die eenmalige posisie van die apostolaat. Jesus Christus sit ná sy hemelvaart sy werk op aarde voort, maar dan deur die apostels wat Hy geroep, uitgestuur en toegerus het met die krag van die Heilige Gees.

Vir hierdie artikel is die verband tussen apostoliese getuienis en die Nuwe Testament van belang. Kruger (2012:181) sê dat die Nuwe Testamentiese geskrifte verstaan kan word as die 'authoritative, foundational, and eyewitness tradition delivered by the apostles of Jesus Christ'. Wanneer Boice (2019:33, 34) handel oor die besondere taak waarvoor Jesus die apostels geroep het en waartoe hulle deur die Gees toegerus is, beklemtoon hy dat die apostels hulle opdrag voltooi het. Hy sê 'The New Testament is the result'. Hierdie artikel is op die volgende vraag toegespits: 'Was die apostels betroubaar en het hulle die boodskap wat aan hulle toevertrou was, betroubaar oorgedra?' Indien die apostels nie ten volle betroubaar was nie, bly die betroubaarheid van die Nuwe Testamentiese geskrifte in die slag al sou dit die apostoliese boodskap dra. Wanneer daar dus 
oor die betroubaarheid van die Nuwe Testament gehandel word, sal ook rekenskap van die betroubaarheid van die apostels gegee moet word.

Wanneer skrywers aan die betroubaarheid van die apostels aandag skenk, word daar meestal gehandel oor Skrifgedeeltes soos Lukas 1:1-4 (Edwards 2015:24-26); Lukas 24:48-49 (Carroll 2012:494); Johannes 14:26 en 16:13-14 (Grudem 2009:60-61); 1 Korintiërs 11:23 (Taylor 2014:270-272); 1 Korintiërs 15:3 (Schreiner 2018:302-303) en Openbaring 1:1-3 (Paul 2018:60; Roeloff 1994:20-21). Die moontlikheid dat die apostel Petrus ${ }^{1}$ in 2 Petrus 1:3-4 ${ }^{2}$ belangrike besonderhede bied aangaande die betroubaarheid van die apostels en hulle getuienis, geniet in die navorsing weinig aandag. Hoewel enkele skrywers soos Bigg (1969:253) en Van Houwelingen (1993:31-32) aanvaar dat die skrywer in 1:3-4 oor die apostels handel, stel hulle nie die betroubaarheid van die apostels en hulle getuienis in besonderhede aan die orde nie.

In hierdie artikel word 1:3-4 binne die konteks van die hele geskrif eksegeties bestudeer en word die inligting wat Petrus in die verse aangaande die apostels en hulle getuienis bied, aangedui. In die eksegese wat in die artikel aangebied word, word die grammaties historiese model gevolg soos wat dit in die gereformeerde tradisie beoefen word (vgl. Breed, Van Rensburg \& Jordaan 2008:45-53; Fee 2009:29-132; Jordaan, Van Rensburg \& Breed 2011:225-258; Tolar 2002:21-38). Die vooronderstelling in hierdie artikel is dat 'the Protestant canon of the OT and the NT composes the divinely inspired, authoritative material for doing biblical theology' (Beale 2011:2). Daarom word met die finale vorm van die Bybelboeke in Hebreeus, Aramees en Grieks in die artikel gewerk. Die outeurs van die onderskeie Bybelboeke word ook geneem soos die betrokke Bybelboeke hulle aandui (vgl. ook voetnoot 1), en die historiese figure en gebeure waarna die betrokke Bybelboeke verwys, word as histories betroubaar geneem (vgl. byvoorbeeld Kruger 2012:181-182). Om 'n ontleding van 2 Petrus se gedagtestruktuur te doen, word die metode gebruik wat Coetzee (1988:19-37; vgl. ook Cotterell \& Turner 1989:230-256) ontwikkel het en Breed (1994:4-5) in meer besonderhede uitgewerk het. Die metode van komponensiële analise soos in Louw and Nida (1988:vi-xx) uiteengesit en deur Breed (1994:6-7) aangepas is, word gevolg wanneer ondersoek na die woordbetekenisse van Griekse woorde gedoen word.

In hierdie artikel word eerstens aandag aan 1:3-4 gegee binne die tekstuele konteks van die geskrif. Tweedens word ondersoek ingestel na die ontvangers van dit wat volgens 1:3 gegee is, en derdens na die goddelike krag wat in 1:3 vermeld word. Daarna word agtereenvolgens aandag gegee aan die doel en die instrument waarmee 'alles' gegee is. Vervolgens

\footnotetext{
1.In vorige navorsing het ek aandag gegee aan die argumente van skrywers wa beweer dat 2 Petrus nie deur die apostel Petrus geskryf is nie. Volgens my bevinding is hierdie argumente nie is hierdie argumente nie 671), Schreiner (2003:255-282) en Van Houwelingen (2010:119-129) toon we oortuigend aan dat daar genoegsame redes is vir die aanvaarding van Petrus se urskap.

2.Verderaan sal alle verwysings na 2 Petrus slegs met hoofstuk- en versnommers aangedui word.
}

word die roeping wat in 1:4 genoem word, ondersoek en daarna geniet die beloftes wat volgens 1:4 gegee is aandag. Ten slotte word tot enkele konklusies gekom.

\section{Petrus 1:3-4 in die tekstuele konteks van die geskrif}

2 Petrus kan in agt gedagte-eenhede ingedeel word. Die eerste gedagte-eenheid (1:1-2) dien as aanhef van die brief. In die tweede gedagte-eenheid (1:3-11) gee Petrus 'n opsomming van sy leer as apostel. In hierdie gedagte-eenheid kom drie kleiner gedagte-eenhede voor, naamlik 'n historiese deel (1:3-4), 'n etiese aanmoedigingsgedeelte (1:5-9) en 'n eskatologiese gedeelte (1:11). In 1:12-15 en 3:1-2 gee Petrus die doel van die skrywe weer. Hierdie twee gedeeltes vorm saam een gedagteeenheid. 2 Petrus 1:16-21 kan as 'n vierde gedagte-eenheid beskou word. In hierdie eenheid fundeer die apostel sy gesag. 'n Waarskuwing teen die valse leraars is in 2:1-22 aan die orde en vorm die vyfde gedagte-eenheid. Vanaf 3:3-18 is daar nog drie gedagte-eenhede. Die sesde gedagte-eenheid is 3:4-16 waarin Petrus handel oor die sekerheid van die Here se koms.

Die sewende gedagte-eenheid (3:17-18a) vorm die slot van die brief en die laaste gedagte-eenheid (3:18b) is 'n lofprysing (Breed 1994:45-77).

Dit is uit die voorafgaande indeling duidelik dat daar'n noue samehang is tussen 1:3-4 en die opvolgende kleiner gedagteeenhede, naamlik 1:5-10 en 1:10. Dit is ook duidelik dat die waarskuwing teen die vals leraars 'n belangrik plek in die brief inneem (vgl. gedagte-eenheid 5). In die eksegese van 1:3-4 behoort dit wat Petrus aangaande die vals leraars bekend maak, deeglik verreken te word. Daar moet ook in die eksegese daarop gelet word dat, hoewel 1:1-2 en 1:3-11 as aparte gedagte-eenhede aangedui word, die voegwoord $\omega \varsigma$ in 1:3 'n aanduiding gee dat daar ' $n$ noue verbinding tussen $1: 1-2$ en $1: 3-4$ is.

\section{Die ontvangers van dít wat volgens 2 Petrus 1:3 gegee is}

Baie eksegete soos Howe (2000:307-309), Kennard (1987:402), Köstenberger (2012:16-17) en Moo (1996:41) aanvaar sonder deeglike motivering dat die skrywer in 1:3-4 met die persoonlike voornaamwoord ons $(\dot{\eta} \mu \tilde{\mathrm{i} v} / \dot{\eta} \mu \tilde{\alpha} \varsigma)$ na homself en al die gelowiges verwys. Die wisseling van die voornaamwoord in die eerste persoon meervoud ons in 1:3-4a na die tweede persoon meervoud julle in 1:4b dui egter in ' $n$ ander rigting. In 1:1 verwys die skrywer na die lesers wat dieselfde geloof as 'ons' ( $\dot{\eta} \mu \mathrm{iv}$ ) ontvang het. Volgens 1:2 is die skrywer se begeerte dat daar genade en vrede aan 'julle'

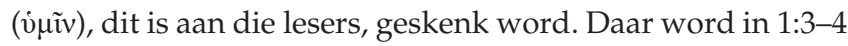

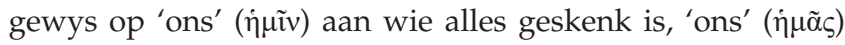
wat geroep is en 'ons' ( $\dot{\eta} \mu \mathrm{i} v)$ aan wie beloftes gegee is. In 1:4b verwys die skrywer weer deur die aoristus werkwoord $\gamma \varepsilon \dot{v} \eta \sigma \theta \varepsilon$ in die tweede persoon meervoud na 'julle'.

Dit is belangrik om daarop te let dat Petrus met 'ons' $(\dot{\eta} \mu \mathrm{iv})$ in 1:1 na homself en die ander apostels verwys 
(vgl. Charles 1997:131; Giese 2012:31; Harink 2009:133) en nie na Petrus en die ander Jode soos soms aanvaar word nie. Dat $\dot{\eta} \mu \tilde{v}$ in 1:1 na Petrus en die ander apostels verwys, word bevestig deur die feit dat die onderskeid tussen Jode en nieJode nie in 2 Petrus ter sprake gebring word nie en dat Petrus wel in 1:16 in die eerstepersoon meervoud $\dot{\varepsilon} \gamma \nu \omega \rho i ́ \alpha \mu \mu \varepsilon v$ na homself en die ander apostels verwys. Indien Petrus in 1:1 dan met 'ons' (i் $\mu \mathrm{i} v)$ na homself en die ander apostels verwys, ontstaan die vraag of die skrywer daarna in 1:3-4 die lesers by 'ons' sal insluit.

Op grond van die volgende redes kan aanvaar word dat Petrus met $\dot{\eta} \mu \tilde{v} / \dot{\eta} \mu \tilde{\alpha} \varsigma$ in 1:3-4 nie na homself en die lesers verwys nie, maar na homself en die ander apostels:

- Dit is duidelik uit 2 Petrus dat die vals leraars die leer van die apostels betwyfel het. Dit blyk byvoorbeeld dat hulle volgens 1:16 dit wat die apostels aangaande die krag en koms van Jesus Christus bekend gemaak het as verdigte

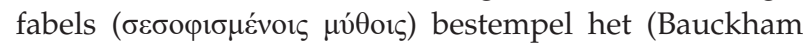
1983:213; Harvey \& Towner 2009:60-62). Omdat die leer van die apostels betwyfel is en Petrus hulle in die brief met groot erns bestry (vgl. gedagte-eenheid 5), is dit moontlik dat hy reeds aan die begin van sy brief oor die apostels sal handel en hulle betroubaarheid beklemtoon.

- Indien $\eta_{\mu i \tau}$ in 1:4a die lesers insluit, is dit moeilik om te verklaar hoekom Petrus in 1:4b van 'ons' na 'julle' verwissel. Volgens 1:4 het 'ons' beloftes ontvang, maar dit

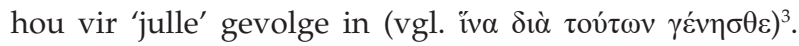
Indien die mense wat die beloftes ontvang het, sowel as die mense vir wie dit gevolge inhou, dieselfde sou wees, sou verwag kon word dat Petrus sou sê dat 'ons' beloftes ontvang en dit hou vir 'ons' gevolge in (vgl. Van Houwelingen 1993:31).

- Soos in punt 2 genoem, dui die voegwoord $\dot{\omega} \varsigma$ in 1:3 moontlik op ' $n$ noue band tussen 1:1-2 en 1:3-4. Wanneer Petrus in 1:1 aandui dat die lesers dieselfde geloof as die apostels ontvang het, gebruik hy die woord $\lambda \alpha \gamma \chi \alpha ́ v \omega$. $\Lambda \alpha \gamma \chi \alpha ́ v \omega$ word in hierdie vers in die semantiese veld 'besit, oordra, verruil', en in die subdomein 'ontvang', gebruik vir die betekenis 'om te ontvang met die implikasie dat die proses met die goddelike wil of guns verband hou' (vgl. Louw \& Nida 1988:30.106). By nadere bestudering van 1:3-4 blyk dit waarskynlik te wees dat die skrywer met die voegwoord $\dot{\omega} \varsigma$ in 1:3 weer die gedagte van 1:1 opneem, naamlik dat die lesers se verkryging van hulle geloof met 'n proses van goddelike wil of guns verband hou. Waarskynlik dui die skrywer in 1:3a met die genitious

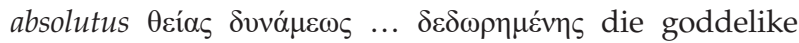
betrokkenheid aan. Hy maak dan verder in 1:3-4a duidelik dat die apostels 'n belangrike plek ingeneem het in die proses waarin die lesers deur goddelike wil of guns geloof ontvang het - dié geloof wat dieselfde waarde het as die apostels se geloof (vgl. 1:1). Wanneer die skrywer in 1:4b vanaf die eerste persoon meervoud 'ons' na die tweede persoon meervoud 'julle' verwissel, dui hy aan waarop die proses wat volgens goddelike wil of guns plaasgevind het, vir die lesers uitgeloop het.

3.Later word aangetoon dat iva in $1: 4 \mathrm{~b}$ doel en gevolg aandui.
Indien aanvaar word dat Petrus in 1:3-4a die verhouding tussen Jesus Christus en die apostels beklemtoon deur te sê dat Jesus Christus se goddelike krag aan die apostels (alles) geskenk het, die apostels sy geroepenes is, dat Jesus Christus aan hulle beloftes geskenk het en ook dat die skrywer in 1:4b die betekenis aandui daarvan dat die apostels beloftes ontvang het, kom dit ooreen met 'n patroon wat in die res van die brief gevind word. Die patroon bevat telkens drie elemente, naamlik die apostel(s) se verhouding met Jesus Christus, die verkondiging deur die apostels en die betekenis vir die lesers. Petrus beklemtoon byvoorbeeld in 1:12-15 sy verhouding met Jesus Christus ${ }^{4}$ (vgl. 1:14) en wys op sy verkondiging in 1:12 met die woord $\dot{\pi} \pi \mu \mu v \eta \underline{\sigma \kappa} \omega$. Die betekenis vir die lesers is dat

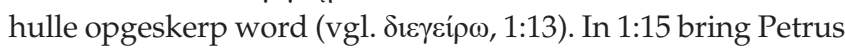
sy verkondiging ter sprake wanneer hy sê hy sal hom beywer

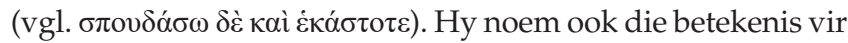
die lesers. Hy wil dat hulle sekere dinge in gedagte sal hou (

In 1:16 beklemtoon die skrywer die apostels se verhouding met Jesus Christus. Hulle was ooggetuies van sy $\mu \varepsilon \gamma \alpha \lambda \varepsilon$ ció $\eta \varsigma$

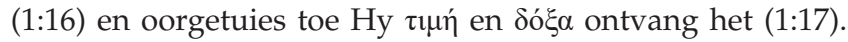
Die apostels se verkondiging kom in 1:16 ter sprake wanneer Petrus na dít verwys wat aan die lesers bekend gemaak is $(\gamma v \omega \rho i \zeta \omega)$. Die gevolge vir die lesers word veronderstel, naamlik dat hulle met sekerheid kan weet dat die apostels nie verdigte fabels verkondig het nie.

Petrus stel ook die band tussen apostels en Jesus Christus, asook die apostels se verkondiging in 3:2 op die voorgrond wanneer hy sê dat die gebod waarna hy in hierdie vers verwys, sowel die apostels se gebod, as Jesus Christus se gebod is (vgl. die genitiewe $\tau \tilde{\omega} v \dot{\alpha} \pi$ $\sigma \omega \tau \tilde{\eta} \rho \varsigma_{)}$). Petrus wil dat die lesers volgens 3:2 hierdie gebod

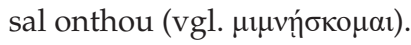

Dit blyk uit voorgaande beredenerings dat Petrus eerder in 1:3-4a met die voornaamwoord $\dot{\eta} \mu \tilde{\mathrm{i}} / \dot{\eta} \mu \tilde{\alpha} \varsigma$ na homself en die apostels as na homself en alle gelowiges verwys.

\section{Die goddelike krag wat aan die apostels (alles) gegee het}

Daar word in 1:3 met die genitivus absolutus $\tau \tilde{\eta} \varsigma$ $\theta$ sías $\delta v v \alpha ́ \mu \varepsilon \omega \varsigma \ldots \delta \varepsilon \delta \omega \rho \eta \mu \varepsilon ́ v \eta \varsigma$ aangedui dat die goddelike krag aan die apostels (alles) gegee het. Dit is moontlik dat Petrus die genitief av̉ $\tau$ ṽ in 1:3 na die goddelike krag van óf God óf Jesus Christus verwys. Albei die goddelike Persone is immers in die voorafgaande sin (1:2) ter sprake. Omdat Jesus Christus die laaste Persoon is wat in 1:2 genoem word, is dit waarskynlik dat dit sy goddelike krag is wat ter sprake is (Richard 2000:326). Die feit dat Petrus Jesus in 1:1 God noem (Callan 2020:24-25) en in 1:16 uitdruklik na Jesus se

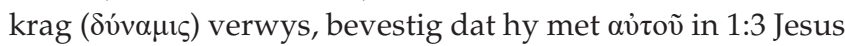
Christus in gedagte het (vgl. Bigg 1969:253).

4.Van Houwelingen (1993:43-44) wys daarop dat Jesus volgens Johannes 21:18-19 aan Petrus duidelik gemaak het dat Petrus in die toekoms ' $n$ marteldood sou sterf. Dit blyk dat Petrus uit sy omstandighede waarin hy verkeer het volgens 1:14, Dit blyk dat Petrus uit sy omstandighede waarin hy verkeer het volgens 1:14,
duidelikheid kry dat die tyd waarna Christus verwys het, aangebreek het. Die duidelikheid kry dat die tyd waarna Christus verwys het,
apostel Petrus se verhouding is dus in 1:14 op die voorgrond. 
Dit is belangrik om duidelikheid te kry waarna Petrus met

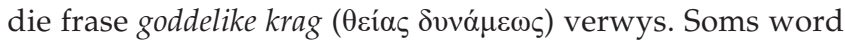
aanvaar dat die skrywer duidelik wil maak dat Jesus Christus in God se goddelike krag deel (vgl. Bauckham 1983:177). Wanneer die woorde egter binne die konteks van die hele brief en ook in die konteks van die Nuwe Testament verstaan word, blyk dit dat Petrus na die Heilige Gees verwys. Dit kan soos volg gemotiveer word:

- In 2 Petrus word die Ou Testamentiese profete en die apostels telkens saam in een gedagte-eenheid vermeld. In 1:16-18 beskryf Petrus wat die apostels gesien en gehoor het. Hy volg dit in 1:19-21 op deur na dieOu-Testamentiese profete (Harvey \& Towner 2009:70-71) te verwys. Volgens 3:1-2 wil Petrus dat die lesers die woorde van die OuTestamentiese profete sowel as die gebod van die apostels sal onthou. Wanneer Petrus in 1:19-21 aan die OuTestamentiese profete aandag gee, is dit belangrik om daarop te let dat hy uitdruklik oor die werking van die Heilige Gees in die profete handel (Green 2008:233). Indien $\tau \tilde{n} \varsigma$ $\theta$ cías $\delta v v o ́ \mu \varepsilon \omega \varsigma$ in 1:3 na die Heilige Gees verwys, beklemtoon Petrus dus reeds aan die begin van die brief dat die Heilige Gees ook, soos in die profete, in die apostels gewerk het.

- Dit is belangrik om daarop te let dat Petrus in sy eerste brief $^{5}$ (1 Pet 1:10-12) noem dat die Gees van Christus aktief in die profete van die Ou Testamentiese bedeling asook in die apostels en hulle medewerkers van die Nuwe Testamentiese bedeling gewerk het (Van Houwelingen 1991:58). Petrus beklemtoon volgens 1 Petrus 1:12 dat die Gees wat in die Nuwe Testamentiese verkondigers gewerk het, uit die hemel gestuur is

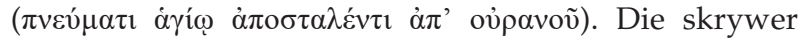
beklemtoon met die passiewe werkwoord $\dot{\alpha} \pi 0 \sigma \tau \alpha \lambda \dot{\varepsilon} v \tau 1$ en met die frase $\dot{\alpha} \pi$ ' ov̉pavoṽ die goddelike inisiatief (Michaels 1988:47-48). Indien aanvaar word dat Petrus met $\tau \tilde{\varsigma}$ $\theta \varepsilon i ́ \alpha_{\varsigma} \delta v v \alpha ́ \mu \varepsilon \omega \varsigma$ in 1:3 na die Heilige Gees verwys en daar dus in 2 Petrus duidelik gemaak word dat die Gees in die apostels, sowel as in die profete (1:21) gewerk het, toon dit 'n duidelike ooreenkoms met dit wat Petrus in sy eerste brief skryf. Indien in ag geneem word dat Petrus in 1:3 die goddelike werking met die

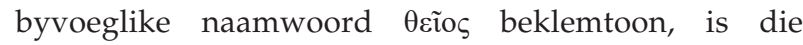
ooreenkoms des te meer treffend.

- Die feit dat Petrus sê dat dit juis Jesus Christus se

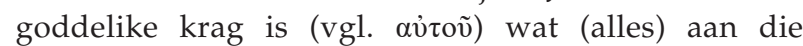
apostels geskenk het, bring dit spesifieke beloftes van Jesus Christus wat in die Johannes-evangelie en in Handelinge opgeteken is, binne die gesigsveld. In die evangelie volgens Johannes word die band van Jesus Christus ná sy hemelvaart met die Heilige Gees sterk beklemtoon. Jesus het volgens Johannes 14:16 gesê dat Hy sal bid dat die Vader die Gees sal stuur. Volgens Johannes 14:26 sal die Vader die Gees in Jesus se Naam stuur (14:26) en, volgens 15:26, sal Jesus self die Gees wat van die Vader uitgaan, stuur. Die Gees sal volgens hierdie vers van Jesus getuig. Ook in Johannes 16:7

5.Green (2006:262-277) wys op die belangrikheid daarvan dat 1 en 2 Petrus as ' "coordinated "Petrine" witness within the Biblical canon' gelees moet word (vgl. ook Wall 2001:46-81) word duidelik gemaak dat Jesus die Gees sal stuur. Uit al hierdie Skrifgedeeltes blyk dit dat die Gees met die oog op 'n kragtige werking in Jesus se volgelinge gestuur word en dat dit tot seën vir die volgelinge is (Martin \& Toney 2018:317). Dit is waarskynlik dat

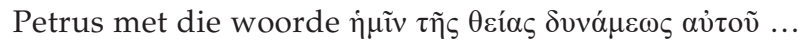
$\delta \varepsilon \delta \omega \rho \eta \mu \varepsilon ́ v \eta \varsigma$ dieselfde gedagtes as Johannes na vore bring, naamlik dat Jesus Christus sy Gees stuur om tot seën in sy volgelinge te werk.

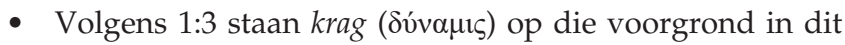
wat aan die apostels gegee is. Volgens Lukas 24:49 het Jesus voor sy hemelvaart die versekering gegee dat die

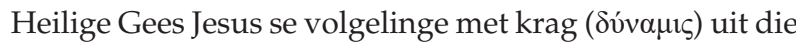
hoogte sal toerus. Jesus se versekering is ook volgens Handelinge 1:8 dat die Gees oor sy volgelinge sal kom en

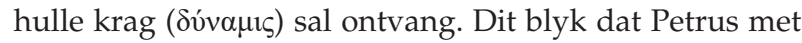

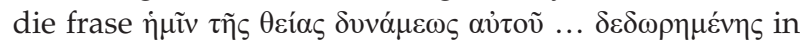
1:3 dieselfde versekering in gedagte het as wat Jesus volgens Lukas 24:49 en Handelinge 1:8 gegee het, naamlik die kragtige werking van die Heilige Gees in Jesus se volgelinge.

Daar kan uit die voorafgaande aanvaar word dat Petrus met die frase $\theta$ cías $\delta v v \alpha ́ \mu \varepsilon \omega \varsigma$ na die werking van die Heilige Gees verwys. Jesus het volgens sy belofte die Gees gestuur om met goddelike krag in die apostels te werk.

\section{Die doel waarmee die Heilige Gees aan die apostels (alles) gegee het}

In 1:3 maak Petrus bekend dat die goddelike krag aan die apostels alles $(\pi \tilde{\alpha} \varsigma)$ gegee het. Hy sê nie uitdruklik wat die inhoud is van hierdie 'álles wat gegee is' nie. Dit is egter duidelik dat Petrus nie die klem op die inhoud van dit wat gegee is, wil laat val nie. Hy wil alleen met die byvoeglike naamwoord $\pi \tilde{\alpha} \varsigma$ benadruk dat dit wat gegee is, genoegsaam is. Petrus wys wel uitdruklik op die doel waarvoor alles gegee is. Hy gebruik die voorsetsel $\pi \rho$ ó $\varsigma$

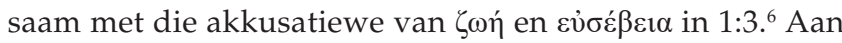

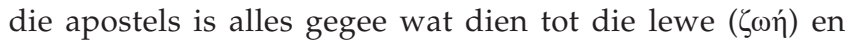

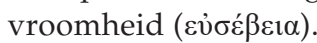

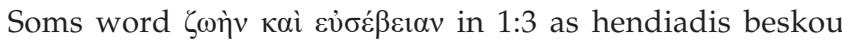
(sien bv. Giese 2012:47-48; Davids 2006:168). Die feit dat 'n ware (ewige) lewe sowel as vroomheid in 2 Petrus aan die orde gestel word, toon aan dat die woorde nie as hendiadis

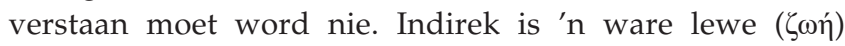
telkens aan die orde in die vele kere (vgl. byvoorbeeld 2:1, $3,9,12,17,19)$ wat Petrus na God se oordeel oor die vals

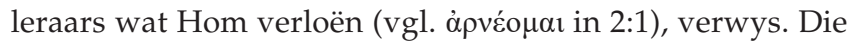
ware lewe is ook ter sprake wanneer Petrus in 1:11 oor die toegang tot die ewige koninkryk van Jesus Christus handel en in 3:13 in die eerste persoon meervoud sê dat ons nuwe

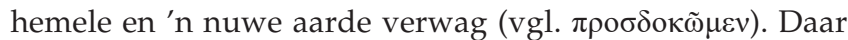
kan met Paulsen (1992:107) saamgestem word wat sê dat

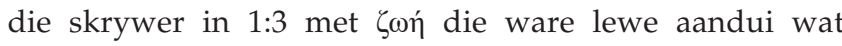
deurlopend in die brief ter sprake is.

6.Jordaan (2014:130-131) wys daarop dat reós saam met ' $n$ akkusatief primêr 'beweging na toe' uitdruk en dus doel kan aandui. 
Ook vroomheid word in die brief beklemtoon. In 1:5-7 word die lesers tot ' $n$ vroom lewe opgeroep wanneer Petrus vereis dat hulle deugde by hulle geloof sal voeg. Die lesers word in 1:8 op die positiewe gevolge gewys indien hulle erns sou maak met 'n lewe vol van die deugde (Breed 2021). In teenstelling met die vroom lewe waartoe die lesers opgeroep word, maak Petrus in die brief duidelik dat die vals leraars byvoorbeeld hebsugtig is (vgl. 2:3) en dat hulle volgens eie begeerlikhede leef (vgl. 3:3; vgl. ook Caulley 2008129-130). Petrus wys met die woord $\varepsilon \dot{\sigma} \sigma \dot{\beta} \beta \varepsilon 1 \alpha$ op die betekenis 'Gedrag wat die regte geloofsoortuiging en houdings openbaar'

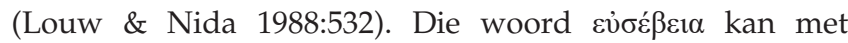
'vroomheid' of 'godsvrug' vertaal word. Petrus verwys dus

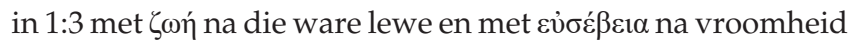
of godsvrug.

Dit is belangrik om te vra waarom Petrus sou wou aantoon dat die apostels alles ontvang het wat tot die ware lewe en tot vroomheid of godsvrug dien. In 2 Petrus is die navolging van óf die apostels óf die vals leraars op die voorgrond (Donelson 2010:236; Giese 2012:208-209). Petrus beklemtoon uitdruklik dat mense wat die vals leraars navolg, ook in hulle eindbestemming, naamlik God se oordeel sal deel (vgl. byvoorbeeld 2:2 en 2:18-22). Daarteenoor maak Petrus duidelik wat die toekoms is van hulle wat die leer van die apostels aanvaar en hulle lewe daarvolgens inrig. Hulle mag seker wees dat die Here en Verlosser, Jesus Christus aan hulle toegang tot sy koninkryk sal verleen (1:11) en hulle mag, soos die apostels (vgl. die eerste persoon meervoud $\pi \rho о \sigma \delta о \kappa \tilde{\mu} \mu \varepsilon v$ in 3:13), nuwe hemele en 'n nuwe aarde verwag (3:13).

Ook die apostels se vroomheid of godsvrug ( $(\varepsilon \dot{\sigma \varepsilon} \beta \varepsilon 1 \alpha v)$ sou as voorbeeld vir die lesers dien. Die vals leraars wat die Here verloën het, het volgens 2:19 aan mense vryheid ( $\dot{\varepsilon} \lambda \varepsilon v \theta \varepsilon \rho i ́ \alpha)$ beloof. Hulle het verkondig dat daar geen oordeel sal wees nie en dat mense vry sal wees om volgens hulle eie drange te leef (Davids 2006:246-247; Donelson 2010:210). Deur in 1:3 te sê dat aan die apostels die ware lewe sowel as godsvrug gegee is, maak Petrus duidelik dat' $n$ ware lewe en vroomheid aan mekaar verbind is. Wie die ware lewe ontvang het, verwerp die vryheid wat die leraars verkondig. Wie die ware lewe ontvang het, sál, soos die apostels, ook vroom lewe.

\section{Die instrument waardeur (alles) aan die apostels gegee is}

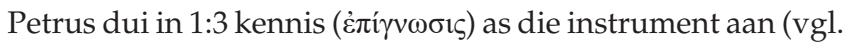

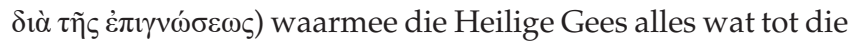
ware lewe en tot 'n vroom of godvrugtige lewe lei, aan die

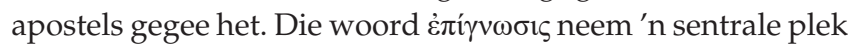

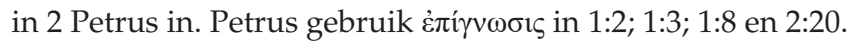
Picirelli (1975:85-93) het in sy navorsing deeglike aandag aan

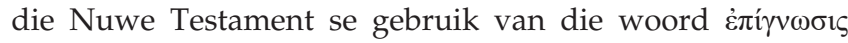

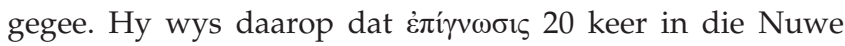
Testament gebruik word en wel in Paulus se latere briewe sowel as Hebreërs en 2 Petrus. Hy (Picirelli 1975:85-93) toon aan dat 'no one explanation of the exact connotation of epignosis will cover all its uses in the New Testament'. Picirelli (1975:85-93)

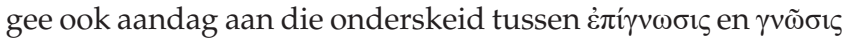
en toon aan dat 'a meaning for epignosis comes more from the context in which it is used than from the force of the epi'.

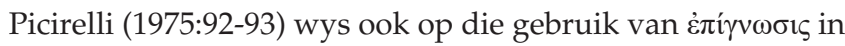

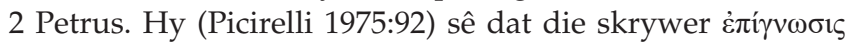
gebruik 'in the sense which is exactly equel to conversion ...' Volgens hom wys Ė $\pi^{\prime} \gamma v \omega \sigma ı$ in 1:2 op kennis deur 'n bekeringervaring en in 1:3, 1:8 en 2:20 op reddende kennis. Wanneer die

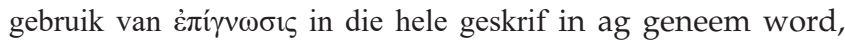

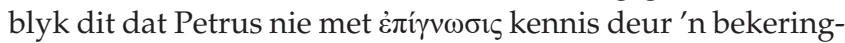
ervaring in gedagte het nie. In 1:8 beklemtoon Petrus die belangrikheid daarvan dat die deugde wat in 1:5-7 genoem word, in die lewe van die lesers sal voorkom. Petrus verbind die teenwoordigheid van hierdie deugde by die lesers aan

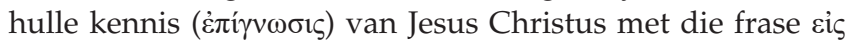

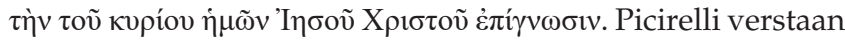

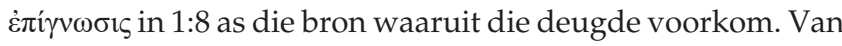
Houwelingen (1988:116) wys egter daarop dat ná 'de twee predikatief gebruikte adjektieven werkeloos en vruchteloos moet de

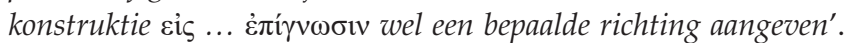
Petrus verseker die lesers in 1:8 dus dat, indien die deugde

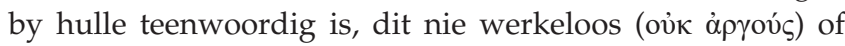

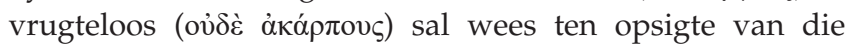
kennis van Jesus Christus nie. Indien die deugde by die lesers teenwoordig is, sal dit hulle ywerig maak en sal dit vrugte dra met betrekking tot die kennis van Jesus Christus (Breed

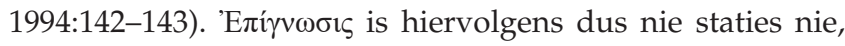
maar kan vermeerder. 'E $\pi$ í $\gamma v \omega \sigma ı \varsigma$ verwys dus nie in 2 Petrus na kennis deur 'n bekering-ervaring nie.

Dit blyk beter te wees om te aanvaar dat Petrus die woord

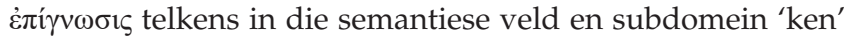
gebruik en wel in die betekenis 'om min of meer afgebakende inligting te besit met moontlik 'n mate van diepgang en bedrewenheid' (Louw en Nida 1988:334). Dit is verder

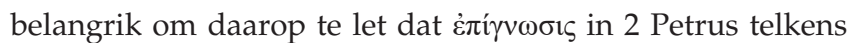
Persone (God en Jesus Christus in 1:2) of 'n Persoon (Jesus Christus in 1:3; 1:8 en 2:20) as objek het. Daar kan met Van Houwelingen (1993:29-30) saamgestem word dat die

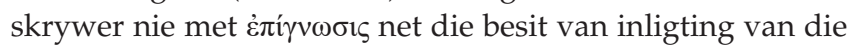
Persone in gedagte het nie, maar 'n verhouding en dan 'n innige en persoonlike verhouding.

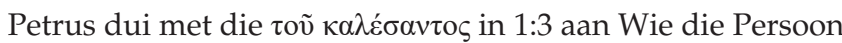
is wat die apostels geken het. Verskeie skrywers (Donelson 2010:2019; Mulholland \& Osborne 2016:289) sê dat dit God is wat volgens 1:3 roep. Dit word gemotiveer deur daarop te wys dat dit gewoonlik God die Vader is wat volgens die Nuwe Testament roep (vgl. Rom 9:24; 1 Tess 4:7 en 2 Tim 1:9). Wanneer daarop gelet word dat Petrus in 1:3 oor die apostels se roeping handel en dat Jesus volgens Skrifgedeeltes soos Matteus 4:21, Markus 1:20 en Lukas 5:1-11 sy apostels geroep het, blyk dit dat Jesus se roeping van sy apostels aan die orde is in 1:3 (vgl. Van Houwelingen 1988:101).

Die Heilige Gees het op 'n baie spesifieke manier aan die apostels alles gegee wat tot die lewe en godsvrug dien. Die innige en persoonlike verhouding van die apostels met Jesus 
Christus ná sy hemelvaart was die instrument waardeur die Heilige Gees alles aan die apostels gegee het. Petrus maak dit dus duidelik dat die Heilige Gees, wat Christus gestuur het, nie buite Christus om in die apostels gewerk het nie. Alleen in ' $n$ innige en persoonlike verhouding met die verheerlikte Jesus Christus was dit moontlik dat die apostels die ware lewe kon ontvang en vroom of godvrugtig kon lewe.

\section{Die apostels as geroepenes van Jesus Christus}

Omdat dit volgens 1:3 Jesus Christus is wat die apostels geroep het (vgl. hierbo), kan aanvaar word dat Petrus die woord $\kappa \alpha \lambda \varepsilon ́ \omega$ in 1:3 gebruik in die semantiese veld 'kommunikasie' en die subdomein 'roep' en wel in die betekenis 'om iemand dringend te versoek om verantwoordelikheid te neem vir 'n spesifieke taak en wat 'n nuwe verhouding impliseer met die een wat dringend versoek' (Louw \& Nida 1988:424). Jesus Christus het die apostels dus 'dringend versoek' om verantwoordelikheid te neem vir 'n spesifieke taak en 'n nuwe verhouding tussen Hom en sy geroepenes word geïmpliseer. Lukas se beskrywing van Jesus se roeping van die apostels in Lukas 5:1-11, werp besondere lig op die roeping waarna Petrus in 1:3 verwys. In Lukas 5 word Jesus se goddelike krag kort voor die roeping van Petrus beskryf. Toe Petrus Jesus se opdrag gehoorsaam en hy met sy boot na die diep water vaar en die nette daar uitgooi, is die vangs so groot dat die nette wou skeur. Dit gebeur nadat Petrus en die ander manne die hele nag niks gevang het nie. Ná hierdie wonderwerk sê Jesus vir Petrus: ' ...van nou af sal jy mense vang'. Edwards (2015:156) som die betekenis van Jesus se woorde soos volg op: 'Jesus has "caught" Peter by a miracle of grace, and He commissions Peter to "catch" people likewise.' Edwards wys ook daarop dat hierdie roeping onweerstaanbaar was. Lukas sê dat Petrus en die ander alles verlaat het en Jesus gevolg het (Luk 5:11). Dit blyk uit Lukas 5 dat die apostels geroep is om God se genade in Christus te verkondig en dat hierdie roeping nie maar net 'n 'dringende versoek' was nie, maar dat die geroepenes onvoorwaardelik gehoor gegee het.

Die feit dat Petrus homself en die ander apostels as geroepenes van Jesus Christus in 1:3 bekendstel, staan in kontras met dit wat hy van die vals leraars sê. Terwyl die apostels volgens 1:3 deur Jesus Christus geroep is en hulle dus die boodskap verkondig van Hom wat hulle geroep

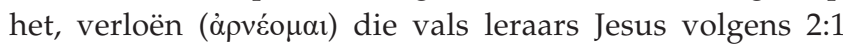
en onderrig hulle mense in valshede (vgl. $\psi \varepsilon v \delta o \delta 1 \delta \alpha ́ \sigma \kappa \alpha \lambda o \varsigma)$. As geroepenes verkondig die apostels die waarheid (vgl. $\dot{\alpha} \lambda \hat{\eta} \theta \varepsilon 1 \alpha$ in 1:12) en die vals leraars leuens.

Petrus verbind in 1:3 die roeping van die apostels met Jesus

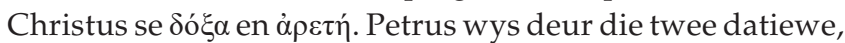
$\delta o ́ \xi \eta$ en $\alpha \hat{\rho} \varepsilon \tau \tilde{y}$, die instrumente aan (vgl. Jordaan 2014:123) waarmee die apostels geroep is. Bauckham (1983:178) sê dat $\dot{\alpha} \rho \varepsilon \tau \tilde{n}$ in die konteks waarbinne dit in 1:3 gebruik word, 'virtually synonymous with $\delta \dot{\xi} \xi \alpha$, and denotes the manifestation of divine power' is. Die feit dat Petrus in 1 Petrus 2:9 die

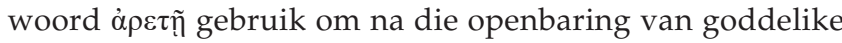
krag te verwys (Jobes 2005:163), dui aan dat Petrus nie $\dot{\alpha} \rho \varepsilon \tau \tilde{n}$ in die semantiese veld 'morele en etiese kwaliteite en verbandhoudende gedrag' gebruik nie, maar in die semantiese veld 'krag, mag' vir die betekenis van die 'manifestasie van krag gekenmerk deur uitsonderlikheid' (vgl. ook Louw \& Nida 1988:682). Dit bevestig Bauckham

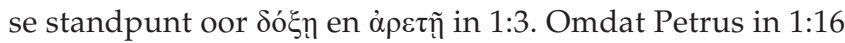

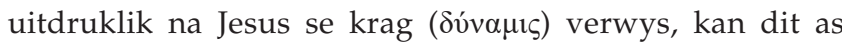
verdere bevestiging dien dat Petrus met die twee woorde, $\delta$ ó $\xi \eta ̣$ en $\dot{\alpha} \rho \varepsilon \tau \tilde{n}$, die manifestasie van Jesus se goddelike krag aandui.

Verdere inligting aangaande Jesus se roeping van sy apostels met die instrumente $\delta$ óg̣ en $\alpha \rho \varepsilon \tau \tilde{n}$ word in 1:16, 18 gebied. Soos reeds voorheen aangetoon, het die vals leraars die apostels beskuldig dat hulle vindingryke fabels

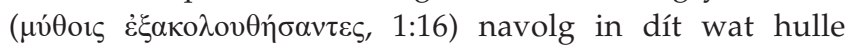
bekend gemaak het. Petrus weerlê hulle beskuldiging deur te wys op wat hy, Jakobus en Johannes op die berg van verheerliking waargeneem het (vgl. Matt 17:1-13, Mark 9:2-13 en Luk 9:28-36). Dit is opvallend dat die drie apostels, volgens 1:16-17, Jesus se majesteit ( $\mu \varepsilon \gamma \alpha \lambda \varepsilon \imath$ ió $\rceil$ ), eer ( $\tau \mu \eta \dot{)})$ en heerlikheid ( $\delta$ ó $\xi \alpha)$ waargeneem het, maar dat

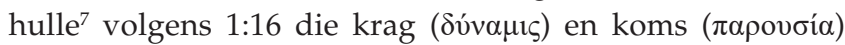
van Jesus Christus bekend gemaak het. Die apostels het dus meer as net dít wat hulle met hulle oë en ore waargeneem het, verkondig. Hulle het die betekenis daarvan verkondig. Die apostels kon uit dít wat hulle waargeneem het, Jesus se kragtige wederkoms ${ }^{8}$ verkondig.

Die feit dat Petrus in 1:16-18 dít wat hy en die ander apostels tydens Jesus se verheerliking waargeneem het as verweer teen die vals leraars se bewerings gebruik het, is belangrik.

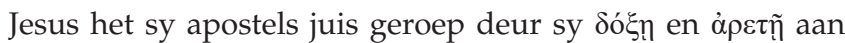
hulle te openbaar sodat hulle die evangelie met sekerheid kon verkondig. Die apostels se verkondiging rus op vaste grond. Hulle het dit wat hulle verkondig, self waargeneem.

\section{Beloftes wat aan die apostels gegee is}

Uit 1:4 is dit duidelik dat Jesus ook aan die apostels beloftes ( $\dot{\varepsilon} \pi \alpha ́ \gamma \gamma \varepsilon \lambda \mu \alpha)$ gegee het. Daar moet gelet word op die feit dat 1:4 met 1:3 verbind word deur die voorsetselfrase $\delta$ ' $\tilde{v} v$. Omdat die skrywer aan die einde van vers 3 na $\delta o ́ \xi \alpha$

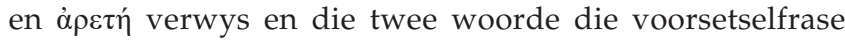
direk voorafgaan, kan daar afgelei word dat $\delta$ ó $\xi \alpha$ en $\dot{\alpha} \rho \varepsilon \tau \dot{n}$ die antesedent van $\delta t^{\prime} \tilde{\omega} v$ is (Davids 2006:171; Schreiner 2003:293; Watson \& Callan 2012:155). Jesus Christus het dus deur sy heerlikheid en goddelike krag ook aan die apostels beloftes gegee.

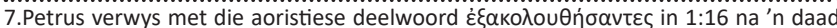
van ál die apostels en nie net na iets wat hyself, Johannes en Jakobus, wat met die verheerliking teenwoordig was, gedoen het nie (vgl. Donelson:2010:231; Green 2008:219).

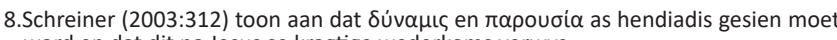
word en dat dit na Jesus se kragtige wederkoms verwys. 
Deur die gebruik van die voegwoord iv $\alpha$ in 1:4b maak Petrus duidelik wat die gevolge (en ook die doel) ${ }^{9}$ vir die lesers was, naamlik dat Jesus Christus aan die apostels die beloftes gegee het. Hy beskryf hierdie gevolge in die twee frases

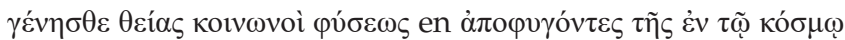
$\dot{\varepsilon} v \dot{\varepsilon} \pi \imath v \mu \mu_{1}^{\alpha} \varphi \theta 0 \rho \tilde{c} s$. Daar kan aanvaar word dat Petrus veronderstel dat die apostels die beloftes wat hulle ontvang het, verkondig het en dat die lesers dit in geloof aanvaar het. Petrus het immers reeds in 1:3 duidelik gemaak dat die apostels deur Jesus Christus geroep is om te verkondig. Dat die lesers dit wat verkondig is, in geloof aanvaar het, blyk uit 1:5 waar Petrus na die geloof ( $\pi i ́ \sigma \tau \iota \varsigma)$ van die lesers verwys. Hulle moet by die geloof - wat hulle reeds het - deugde

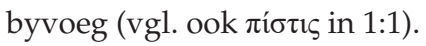

Petrus sê nie uitdruklik na watter beloftes hy in 1:4 verwys nie. Hy noem wel dat die beloftes groot waarde het ( $\tau i ́ \mu 10 \varsigma)$ en uiters belangrik is ( $\mu \varepsilon ́ \gamma 1 \sigma \tau$ $)$ ) (Louw \& Nida 1988:620, 627). In 2 Petrus is daar duidelike aanduidings na watter beloftes Petrus verwys. Daar kan op die volgende beloftes gewys word:

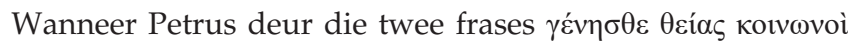

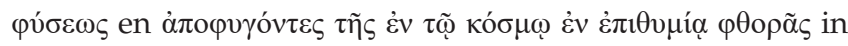
$1: 4 b$ aandui wat die gevolge is van die feit dat die lesers die beloftes wat die apostels aan hulle verkondig het in geloof aanvaar het, gee hy 'n duidelike aanduiding van die beloftes wat hy in 1:4a in gedagte het. Breed (2021), gebaseer op Wolters (1990:28-44), toon aan dat Petrus deur die woord rívouar in 1:4 wys op die betekenis 'om 'n staat of toestand te verkry' (vgl. Louw \& Nida 1988:154). Petrus dui hierdie nuwe staat wat die gelowige lesers verkry het aan deur die

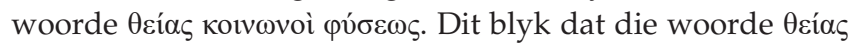

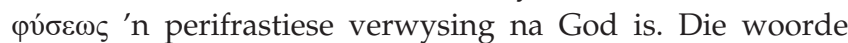
verwys dus nie, soos dikwels aanvaar word, na 'n goddelike natuur $^{10}$ nie, maar na Iemand, naamlik God. Daar kan verder saam met Breed (2021) en Wolters (1990:32-40)

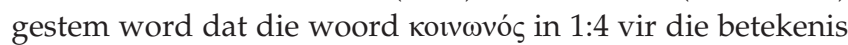
'vennoot' gebruik word (vgl. Louw \& Nida 1988:447). Hierdie vennootskap moet verstaan word in die konteks van die verbond, naamlik die verbond wat op verskeie plekke in die Ou en die Nuwe Testament ter sprake is (vgl. Grudem 2009:515-522). Petrus maak in 1:4b duidelik dat die lesers wat die beloftes wat die apostels verkondig het in geloof aanvaar het, verbondsvennote van God geword het.

Dit is moontlik om uit 2 Petrus nog nader te bepaal hoekom die aanvaarding van die beloftes tot ' $n$ verandering in status sou lei. In 2:1 verwys Petrus na die Here wat mense vrygekoop ( $\dot{\alpha} \gamma o \rho \alpha ́ \zeta \omega)$ het. Dit is duidelik dat Petrus die woord $\dot{\alpha} \gamma o \rho \alpha ́ \zeta \omega$ in die semantiese veld 'beheer, regeer' en in die subdomein 'losmaak, vrylaat' gebruik en wel vir die betekenis 'om te veroorsaak dat iemand vrykom deur 'n middel wat vir die persoon wat die vryheid veroorsaak, hoë koste inhou' (Louw \& Nida 1988:488). Dit blyk dat Petrus met die woord

9.Louw and Nida (1988:783) wys daarop dat wanneer iva gevolg aandui, dit dikwels ook indirek na doel verwys (vgl. ook Jordaan 2014:81).

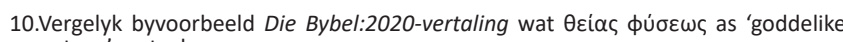
natuur' vertaal.

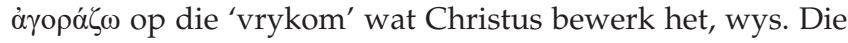
middel wat hoë koste ingehou het en waarmee Hy vryheid bewerk het, is - soos wat Petrus dit volgens 1 Petrus 1:19

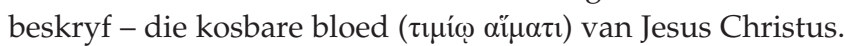
In 2:1 handel Petrus oor die vals leraars wat die Here, wat

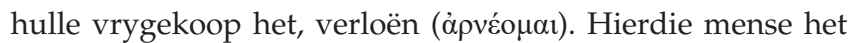
daarop aanspraak gemaak dat hulle vrygekoop is. Hulle lewenswandel het egter getoon dat hulle ongelowig en ongehoorsaam is en nie werklik vrygekoop is nie (Schreiner 2003:331). Hierteenoor verwys Petrus in 1:5-10 na die lesers wat wel geloof het en wat deugde by hulle geloof moet voeg. Daar kan dus afgelei word dat een van die beloftes waarna Petrus in 1:4 verwys, die versekering is dat elkeen wat in Jesus Christus glo deur die kosbare bloed van Jesus Christus vrygekoop is en 'n verbondsvennoot van God geword het.

Breed (2021) wys daarop dat die toestand waarin die lesers was voordat hulle verbondsvennote van God geword het in 1:4b uitgelig word. Hy (Breed 2021) toon aan dat die woord

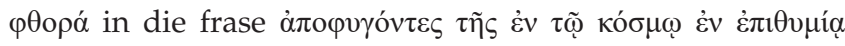
$\varphi \theta 0 \rho \tilde{\alpha} \varsigma$ in die betekenis " $n$ toestand van morele vuilheid en verdorwenheid' gebruik word (vgl. Louw \& Nida 1988:771).

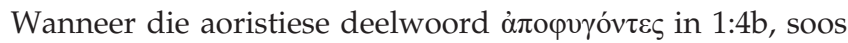
Breed (2021) aantoon, as ingressiewe aoristus verstaan word en dus die begin van ' $n$ handeling aandui (vgl. Jordaan 2014:13), blyk dit dat Petrus in 1:4b sê dat die lesers wat in 'n verbondsvennootskap met God verkeer, begin het om die staat van onreinheid te ontvlug. Anders as die vals leraars wat deur hulle dade en leer die Here verloën het (2:1), het die lesers begin om die morele vuilheid en verdorwenheid te ontvlug. Die belofte dat hulle wat in Jesus Christus glo deur die kosbare bloed van Jesus Christus vrygekoop is en verbondsvennote van God geword het, behels dus ook dat hierdie gelowiges nie in morele vuilheid en verdorwenheid vasgevang sal wees nie, maar dit sal begin ontvlug:

- Petrus se beskrywing in 1:16-18 van die gebeure op die berg van verheerliking, bied ook 'n aanduiding van 'n belofte wat die apostels ontvang het. Soos reeds aangedui is, het Petrus en die ander twee apostels Jesus se majesteit

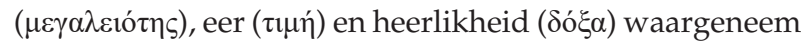
en kon die apostels uit dit wat waargeneem is, sy kragtige wederkoms bekendmaak. Hierdie wederkoms hou verband met die beloftes waarna Petrus in hoofstuk 3 verwys. Die skrywer:

... emphasize that Christ will come with such divine power
since the heretics have denied the final judgment and
cataclysmic end (3:10-13). His return will be the moment
that ushers in the 'day of God', a time when all creation as
we know it will be submitted to divine judgment, with the
promise of a new heaven and new earth (Green 2008:219).

- In die eskatologiese gedeelte (1:11) van die apostel Petrus se leer (1:3-11; vgl. bo) is 'n belofte aangaande toegang tot 'n koninkryk ter sprake. Petrus handel in 1:11 oor gelowiges se 'final salvation' (Bauckham 1983:193). Wat in 1:11 opmerklik is, is die versekering dat die toegang tot hierdie koninkryk ryklik verleen sal word ( $\pi \lambda$ ovoíws $\dot{\varepsilon} \pi \chi 0 \rho \eta \gamma \eta \theta \dot{\sigma} \sigma \varepsilon \tau \alpha \iota)$. Hoewel die voorafgaande verse (vv. 5-10) klem op die lesers se verantwoordelikheid lê, 
word die belofte van toegang tot die koninkryk nie gemaak omdat mense dit deur hulle werke verdien nie. Charles (1997:152) wys tereg daarop dat dit volgens 1:11

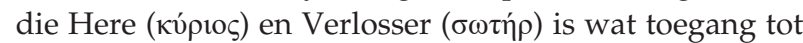
sy koninkryk verleen: 'Entrance is grace, all grace, lavishly provided at no (human) expence'. Die belofte in 1:11 is duidelik: gelowiges wat hulle geloof in die Here en Verlosser, Jesus Christus deur 'n vroom of godvrugtige lewe bevestig, mag seker wees dat hulle Verlosser aan hulle vrye toegang tot sy koninkryk sal bied.

\section{Konklusies}

Daar kan eerstens tot ' $n$ aantal konklusies gekom word wat betrekking het op die betroubaarheid van die apostels en hulle getuienis; en tweedens, tot 'n enkele verdere konklusie wat betrekking het op die betroubaarheid van die Bybel.

Rakende die apostels en hulle getuienis blyk dit dat Petrus in 1:3-4 in besonderhede die betroubaarheid van die apostels en hulle getuienis uitspel. Eerstens is die betroubaarheid van die apostels volgens die verse die gevolg van goddelike krag en inisiatief en nie van menslike vermoëns nie. Jesus Christus het deur sy Gees, wat Hy volgens sy belofte gestuur het, met goddelike krag in die apostels gewerk.

Tweedens het Jesus Christus deur die goddelike krag van die Heilige Gees waarmee Hy in die apostels gewerk het, aan hulle alles geskenk wat tot die ware lewe lei. Vanweë hierdie ware lewe wat die apostels ontvang het, was hulle nie, anders as die mense wat Jesus Christus verloën, bestem vir God se oordeel nie. Hulle was seker van vrye toegang tot Jesus Christus se ewige koninkryk. Deur goddelike krag is alles ook aan die apostels gegee wat tot vroomheid of godvrugtigheid lei. Die apostels wat die ware lewe ontvang het en wie se lewe vroom of godvrugtig was, het self 'n getuienis geword aan almal wat bely dat Jesus Christus hulle deur sy kosbare bloed vrygekoop het. Deur goddelike krag het die apostels 'n getuienis geword dat elkeen wat die ware lewe deur Jesus Christus se verlossingswerk ontvang het, vroom of godvrugtig sál lewe.

Derdens was die apostels se verhouding met Christus ná sy hemelvaart innig en persoonlik. Dit is juis binne hierdie innige en persoonlike verhouding dat die apostels deur die goddelike krag van die Heilige Gees alles ontvang het wat aan hulle gegee is. Alleen binne hierdie verhouding was dit moontlik dat hulle in die ware lewe kon deel, en alleen binne hierdie verhouding kon hulle vroom of godvrugtig leef. Hierdie innige en persoonlike verhouding van die apostels met die verheerlikte Christus is vir gelowiges tot ' $n$ voorbeeld. Buite die verheerlikte Christus om is daar geen ware lewe nie - net God se oordeel. Buite Hom om is daar ook geen vroom of godvrugtige lewe nie; slegs gevangenisskap in 'n morele vuil en verdorwe lewe.

In die vierde plek blyk dit uit 1:3-4 dat Jesus Christus self sy apostels geroep het. Hy het hulle onweerstaanbaar geroep en hulle uitgestuur om God se genade in Jesus Christus te verkondig. As geroepenes het hulle met die gesag van hulle Sender sy evangelie verkondig. Omdat hulle oog- en oorgetuies was van Jesus Christus se goddelike krag, was dit wat hulle ná Jesus se hemelvaart verkondig het, nie verdigte fabels nie. Hulle kon betroubaar die betekenis van dit wat hulle waargeneem het, bekend maak.

Dit is in die vyfde plek duidelik dat die apostels as geroepenes van Jesus Christus beloftes van Hom ontvang het - grootse beloftes. Hierdie beloftes moes hulle verkondig. Vir mense wat hierdie beloftes in geloof aanvaar, is daar belangrike gevolge. Soos blyk uit die brief 2 Petrus, sluit hierdie beloftes in dat hulle wat in geloof aanvaar dat Jesus Christus hulle Here en Verlosser is en dat Hy hulle met sy kosbare bloed vrygekoop het, mag seker wees dat hulle verbondsvennote van God geword het. Hierdie belofte sluit in dat verbondsvennote van God nie in morele vuilheid en verdorwenheid vasgevang is nie, maar sal begin om dit te ontvlug. Hulle wat deur Jesus Christus vrygekoop is, mag, soos die apostels, nuwe hemele en 'n nuwe aarde verwag en mag ook weet dat die Here en Verlosser Jesus aan hulle vrye toegang tot sy koninkryk sal gee.

Met betrekking tot die Bybel kan die gevolgtrekking gemaak word dat Petrus se getuienis in 1:3-4 van groot belang is wanneer daar gevra word na die Bybel se betroubaarheid. Die Nuwe Testamentiese geskrifte is draers van die apostoliese getuienis. Omdat die betroubaarheid van die apostels en hulle getuienis, soos Petrus in 1:3-4 getuig, nie die gevolg is van menslike vermoëns nie, maar van goddelike krag, mag gelowiges met sekerheid, nederigheid en dankbaarheid reken op die betroubaarheid van die Nuwe Testament.

\section{Erkenning Mededingende belange}

Die outeur verklaar dat daar geen finansiële of persoonlike verbintenis is met enige party wat hom nadelig kon beïnvloed in die skryf van hierdie artikel nie.

\section{Outersbydrae}

D.G.B. was die enigste outeur betrokke by die skryf van die artikel.

\section{Etiese oorwegings}

Hierdie artikel volg alle etiese standaarde vir navorsing.

\section{Befondsing}

Hierdie navorsing het geen spesifieke toekenning ontvang van enige befondsingsagentskap in die openbare, kommersiële of nie-winsgewende sektore.

\section{Data beskikbaarheid}

Die outeur bevestig dat die data wat die bevindinge van hierdie studie ondersteun, beskikbaar is in die artikel. 


\section{Vrywaring}

Die sienings en menings wat in hierdie artikel uitgedruk word, is dié van die outeur en weerspieël nie noodwendig die amptelike beleid of posisie van enige geaffilieerde verwantskap van die outeur nie.

\section{Literatuurverwysings}

Bauckham, R.J., 1983, Jude, 2 Peter, TX Word Books, Waco, TX. (Word Biblical Commentary, 50).

Beale, G.K, 2011, A New Testament biblical theology: The unfolding of the Old Testament in the New, Baker Publishing Group, Grand Rapids.

Bigg, C., 1969, A critical and exegetical commentary on the epistles of St. Peter and St Jude, T\&T Clark, Edinburgh. (The International Critical Commentary).

Boice, J.M., 2019, Foundations of the Christian faith: A comprehensive \& readable theology, InterVarsity Press, Downers Grove, IL.

Breed, D.G., 1994, 'Die kenmotief in 2 Petrus. 'n Eksegetiese studie', ThD proefskrif, PU vir $\mathrm{CHO}$, Potchefstroom

Breed, D.G., 2021, 'Breed se bybelse pastorale model Skriftuurlik begrond in 2 Petrus 1:3-11: 'n Eksegetiese toeligting', In die Skriflig 55(2), a2673. https://doi. org/10.4102/ids.v55i2.2673.

Breed, D.G., Van Rensburg, F.J. \& Jordaan, G.J.C., 2008, Manlik en vroulik in die kerk: geslagtigheid en die besondere dienste, Potchefstroomse Teologiese Publikasies, Potchefstroom.

Callan, T., 2020, A voyage around the second letter of Peter: Collected essays, PickWick Publications, Eugene, OR

Carroll, J.T., 2012, Luke. A commentary, the New Testament library, WJK, Louisville, KY.

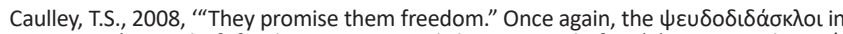
2 Peter', Zeitschrift für die neutestamentliche Wissenschaft 99(1), 129-138. https:// doi.org/10.1515/ZNTW.2008.010

Charles, J.D., 1997, 'Virtue amidst vice: The catalog of virtues in 2 Peter 1', Journal for the Study of the New Testament, suppl. ser. 150, pp. 7-201, Sheffield Academic the Study of the New Testament, suppl. ser. 150, pp.
Press, Sheffield. https://doi.org/10.1093/jts/50.1.257.

Coetzee, J.C., 1984, Die kanon van die Ou en die Nuwe Testament, Wesvalia Boekhandel, Potchefstroom.

Coetzee, J.C., 1988, 'Gedagtestruktuurontleding en die eksegese van die Heilige Skrifte', in J.C. Coetzee (red.), Koninkryk, Gees en Woord, bl. 19-37, NG Kerkboekhandel, Pretoria

Cotterell, P. \& Turner, M., 1989, Linguistics and biblical interpretation, InterVarsity Press, Downers Grove, IL.

Davids, P.H., 2006, The letters of 2 Peter and Jude, WB Eerdmans, Grand Rapids, MI. (The Pillar New Testament Commentary).

Donelson, L.R., 2010, I \& II Peter and Jude: A commentary, Westminster John Knox Press, Louisville, KY. (The New Testament Library).

Edwards, J.R., 2015, The Gospel according to Luke, WB Eerdmans, Grand Rapids, MI. (The Pillar New Testament Commentary).

Fee, D.G., 2009, New Testament exegesis: A handbook for students and pastors, Westminster John Knox Press, Louisville, KY.

Giese, C.P., 2012, A theological exposition of sacred scripture. 2 Peter and Jude, Concordia Publishing House, Saint Louis, MO. (Concordia Commentary).

Green, G., 2008, Jude and 2 Peter, Baker Academic, Grand Rapids, MI. (Baker Exegetical Commentary on the New Testament).

Green, J.B., 2006, 'Narrating the Gospel in 1 and 2 Peter', Interpretation: A Journal of Bible and Theology 60(3), 262-277. https://doi.org/10.1177/002096430606000303

Grudem, W.A., 2009, Systematic theology: An introduction to biblical doctrine, InterVarsity Press, Leicester, MA.

Harink, D., 2009, 1 \& 2 Peter, Brazos Press, Grand Rapids, MI. (Brazos Theological Commentary on the Bible).

Harvey, R. \& Towner, P.H., 2009, 2 Peter \& Jude, InterVarsity Press, Downers Grove, IL. (The IVP New Testament Commentary Series).

Holmes, M.W., Lightfoot, J.B. \& Harmer, J.R., 2007, The apostolic fathers: Greek texts and English translations, Baker Academic, Grand Rapids, MI.
Howe, F.R., 2000, 'The Christian life in Peter's theology', Bibiotheca Sacra 157 (July-September), 304-314.

Jobes, K.H., 2005, 1 Peter, Baker Academic, Grand Rapids, MI. (Baker Exegetical Commentary on the New Testament).

Jordaan, G.J.C., 2014, Die binnewerk van Antieke Grieks. Die semantiek van grammatiese konstruksies: Handleiding vir eksegete en ander studente van Klassieke en Nuwe-Testamentiese Grieks, Potchefstroom Teologiese Publikasies, Potchefstroom.

Jordaan, G.J.C., Van Rensburg, F.J. \& Breed, D.G., 2011, 'Hermeneutiese vertrekpunte vir gereformeerde eksegese', In die Skriflig/In Luce Verbi 45(2/3), 225-258. https://doi.org/10.4102/ids.v45i2/3.14

Kennard, D.W., 1987, 'Petrine redemption: Its meaning and extend', The Journal of the Evangelical Theological Society 30(4), 299-405.

Kruger, M.J., 1999, 'The authenticity of 2 Peter', Journal of the Evangelical Theological Society 42(4), 645-671.

Kruger, M.J, 2012, Canon revisited: Establishing the origins and authority of the New Testament books, Illinois Crossway, Wheaton, IL.

Köstenberger, A., 2012, 'Excellence: The character of God and the pursuit of the scholarly virtue', The Chriswell Theological Lectures 10(1), 13-19.

Louw, J.P. \& Nida, E.A., 1988, Greek-English lexicon of the New Testament based on semantic domains, vol. 1, United Bible Societies, New York, NY.

Martin, R.P. \& Toney, C.N., 2018, New Testament foundations: An introduction for students, Cascade Books, Eugene, OR.

Michaels, J.R., 1988, 1 Peter, Zondervan, Grand Rapids, MI. (Word Biblical Commentary, 49).

Moo, D.J., 1996, 2 Peter, Jude, Zondervan, Grand Rapids, MI. (The NIV Application Commentary).

Mulholland, R. \& Osborne, G., 2016, James, 1-2 Peter, Jude, Tyndale House Publishers, Carol Stream, IL. (Revelation Cornerstone Biblical Commentary).

Paul, I.P., 2018, Revelation: An introduction and commentary, InterVarsity Press, London. (Tyndale New Testament Commentaries, 20).

Paulsen, H., 1992, Der Zweite Petrusbrief und der Judasbrief, Vandenhoeck, Göttingen. (Meyers Kritisch-Exegetischer Kommentar über das Neue Testament).

Picirelli, R.E., 1975, 'The meaning of “Epignosis”', The Evangelical Quarterly 47(2), 85-93.

Richard, E., 2000, Reading 1 Peter, Jude, and 2 Peter: A literary and theological commentary, Smyth \& Helwys, Macon, GA.

Roeloff, J., 1994, Revelation: A continental commentary, Fortress Press, Minneapolis, MN.

Schreiner, T.R., 2003, 1, 2 Peter, Jude, B\&H Publishing Group, Nashville, TN. (The New American Commentary, 37)

Schreiner, T.R., 2018, 1 Corinthians: An introduction and commentary, InterVarsity Press, London. (Tyndale New Testament Commentaries, 7).

Taylor, M., 2014, 1 Corinthians: An exegetical and theological exposition of holy scripture, B\&H Publishing Group, Nashville, TN. (The new American Commentary, 28).

Tolar, W.B., 2002, 'The grammatical-historical method', in B. Corley, S. Lemke \& G.I. Lovejoy (eds.), Biblical hermeneutics: A comprehensive introduction to interpreting scripture, pp. 21-38, Broadman \& Holman Publishers, to interpreting

Van Houwelingen, P.H.R., 1988, 'De Tweede Trompet. De authenticiteit van die tweede brief van Petrus', ThD Proefschrift, Theologische Universiteit, Kampen.

Van Houwelingen, P.H.R., 1991, 1 Petrus. Rondzendbrief uit Bablilon, JH Kok, Kampen. (Commentaar op het Nieuwe Testament).

Van Houwelingen, P.H.R., 1993, 2 Petrus en Judas. Testament in tweevoud, JH Kok, Kampen. (Commentaar op het Nieuwe Testament).

Van Houwelingen, P.H.R., 2010, 'The authenticity of 2 Peter: Problems and possible solutions', European Journal of Theology 19(2), 119-129.

Wall, R.W., 2001, 'The canonical function of 2 Peter', Biblical Interpretation 9(1), 46-81. https://doi.org/10.1163/156851501300112362

Watson, D.F. \& Callan, T.D., 2012, First and second Peter, Baker Academic, Grand Rapids, MI. (Paideia Commentaries on the New Testament).

Wolters, A.M., 1990, “'Partners of the deity”: A covenantal reading of 2 Peter 1:4', Calvin Theological Journal 25(1), 28-44. 